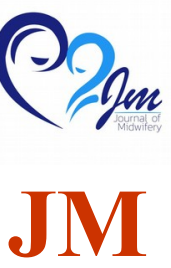

Volume 8 No. 1 (April 2020)

(C) The Author(s) 2020

\title{
ANALISIS FAKTOR RISIKO KEJADIAN POSTPARTUM BLUES DI PUSKESMAS PERUMNAS KABUPATEN REJANG LEBONG
}

\section{ANALYSIS RISK FACTORS INCIDENCE OF POSTPARTUM BLUES IN PUBLIC HEALTH CENTER OF REJANG LEBONG DISTRICT}

\author{
RATI PURNAMA SARI, AZMIZA DENSY, BUYUNG KERAMAN \\ JURUSAN KEBIDANAN, POLTEKKES KEMENKES PADANG, \\ PUSKESMAS CURUP, \\ JURUSAN KESEHATAN MASYARAKAT STIKES TRI MANDIRI SAKTI \\ Email: ratipurnamasariab@gmail.com
}

\begin{abstract}
ABSTRAK
Postpartum blues merupakan salah satu masalah yang mugkin muncul setelah masa persalinan. Postpartumblues yang tidak tuntas dapat berlanjut menjadi depresi postpartum. Penelitian ini bertujuan untuk mengetahui faktor-faktor yang berhubungan dengan kejadian postpartum blues di Puskesmas Perumnas Kabupaten Rejang Lebong. Jenis penelitian ini deskriptif analitik dengan pendekatan cross sectional. sampel dalam penelitian ini sebanyak 43 orang dengan menggunakan alat skrining Edinnburg Postnatal Depression Scale (EPDS). Penelitian dilakukan di Kabupaten Rejang Lebong pada bulan juli 2018. Data diambil dengan instrument test dan lembar observasi. Uji statistik dilakukan dengan Chi Square dan uji satistik Contigency Coefficient. Hasil analisis univariat menunjukkan bahwa hampir sebagian responden tidak mengalami kejadian postpartum blues (normal), Hampir seluruh responden memiliki rentang usia 20-35 tahun, paritas sebagian besar responden adalah primipara, sebagian besar responden memiliki pendidikan Sekolah Dasar (SD sederajat) dan sebagian besar responden tidak mendapatkan dukungan suami dalam perawatan dan pertolongan bayi pasca melahirkan. Ada hubungan antara faktor paritas, dukungan suami, pendidikan dan usia dengan postpartum blues di puskesmas Perumnas Kabupaten Rejang Lebong.
\end{abstract}

Kata Kunci: postpartum blues, dukungan suami, paritas, tingkat pendidikan, usia

\begin{abstract}
Postpartum blues is a psychological impact that might happen after the labor process. Unfinished postpartum blues is potential be Postpartum Depression. The aim of this study is to determine analysis risk factors incidence of postpartum blues in Perumnas Public Health Center of Rejang Lebong District. This study used the observational approach with a cross-sectional design. Samples in this study were 43 people used screening instrument of Edinburg Postnatal Depression Scale (EPDS). This study was conducted in Rejang Lebong District in July 2018.
\end{abstract}


Data obtained with instrument test and observation sheet. Data analysis used the Chi-Square test $\left(\mathrm{X}^{2}\right)$ and contingency coefficient $(\mathrm{C})$. The result of this study showed slightly mothers were not postpartum blues. Most of the respondents were of 20-35 years. More parity of respondents was primipara. A small part of the respondents had a higher education level. Quite of them got unsupported husband in caring and helping baby during postnatal. Result of the bivariate analysis showed that there was a significant relationship between parity, husband support, education level, and age with the incidence of Postpartum Blues in Perumnas Public Health Center Rejang Lebong District.

\section{Keywords: postpartum blues, husband support, parity, education level, age}

\section{PENDAHULUAN}

Masih banyak postpartum blues yang belum teridentifikasi karena anggapan masyarakat tentang gangguan psikologis merupakan hal yang wajar sebagai naluri ibu dan sikap protektif terhadap bayinya. Angka insiden depresi postpartum blues di indonesia 1 sampai 2 per 1000 kelahiran. Sekitar 50 sampai $60 \%$ perempuan yang mengalami depresi postpartum saat mereka memiliki anak pertama dan sekitar $50 \%$ perempuan yang mengalami post partum mempunyai riwayat keluarga gangguan mood (Wahyuni, 2016).

Kebanyakan penderita dideteksi bila kondisinya sudah mengalami depresi berat (Postpartum psychosis). Kejadian postpartum blues akibat adanya kecenderungan gangguan mood pada ibu usia muda memungkinkan menjadi salah satu faktor risiko terjadinya postpartum blues (Machmudah, 2010). Keadaan tersebut akan makin menyulitkan bila ditambah dengan tekanan psikologi, sosial ekonomi, sehingga memudahkan terjadinya gangguan kejiwaan pasca persalinan (Nunung.S. 2013).

Wanita penderita di masyarakat pada umumnya tidak menampakkan gejala depresi karena mereka takut dan malu mendapat anggapan bahwa mereka tidak mampu menjalankan peran sebagai ibu. Kebanyakan penderita yang mencari pertolongan datang ke pelayanan kesehatan, hanya sedikit mengungkapkan perasaan depresi mereka tetapi hanya melaporkan gejala fisik yang mengganggu. Apabila postpartum blues berlanjut maka akan berkembang menjadi depresi post partum. Ibu dapat merasakan kesedihan, susah berkonsentrasi, perasaan bersalah dan tak berharga. Depresi postpartum blues dapat mengakibatkan gangguan psikologis dalam jangka pendek dan jangka panjang. Postpartum blues sindrom ini hampir terjadi 80 persen di alami oleh ibu yang pertama kali melahirkan (Nugroho. T, 2014).

Depresi yang tidak tertangani dengan baik akan mengakibatkan post partum psikosis yang mengakibatkan perubahan mood secara drastis dan sering memicu terjadinya tindakan ekstrim seperti bunuh diri dan membunuh bayi yang baru dilahirkannnya. Depresi postpartum blues bukan saja berdampak besar kepada keadaan ibu tetapi juga terhadap anaknya,sulitnya interaksi antara ibu yang sempat mengalami depresi dengan anaknya meningkatkan resiko gangguan tingkah laku dan gangguan kognitif bahkan dapat membahayakan anak.oleh sebab efek tersebut alat skrining untuk mendiagnosis awal sangatlah penting. (Dewi, 2014).

Faktor-faktor yang mempengaruhi postpartum blues, antara lain usia, paritas, tingkat pendidikan, dukungan sosial keluarga terutama suami, tingkat pengetahuan, jenis persalinan, kehamilan yang tidak diinginkan, ibu yang bekerja tau tidak bekerja, status sosial ekonomi, faktor hormonal dan psikologi. Keadaan tersebut akan makin menyulitkan bila ditambah dengan tekanan psikologi, sosial ekonomi, sehingga memudahkan terjadinya gangguan kejiwaan pasca persalinan (Nunung,S. 2013).

Berdasarkan survey awal di puskesmas 
perumnas Kabupaten Rejang Lebong pada tanggal 29 januari 2018 Tercatat 52 kasus postpartum blues tahun 2017 dari 320 orang persalinan di puskesmas perumnas kecamatan curup tengah, Sedangkan di Dinas kesehatan kabupaten Rejang lebong pada tahun 2016 terlapor 75 kasus postpartum blues. Hal ini di karenakan beberapa faktor yaitu umur, paritas, pendidikan, dan dukungan keluarga, Meskipun postpartum blues merupakan gangguan psikologi yang ringan namun jika tidak tertangani dengan baik dapat berkembang menjadi gangguan psikologi yang lebih berat. Tujuan penelitian ini adalah untuk mengetahui faktor-faktor risiko yang berhubungan dengan kejadian postpartum blues di Puskesmas Perumnas Kabupaten Rejang Lebong.

\section{METODE PENELITIAN}

Jenis penelitian yang digunakan dalam penelitian ini adalah penelitian analitik dengan menggunakan rancangan crosssectional. Populasi dalam penelitian ini adalah seluruh ibu nifas pada bulan juli di wilayah kerja puskesmas Perumnas Kabupaten Rejang Lebong sejumlah 43 orang. Pengambilan sampel pada penelitian ini adalah dengan menggunakan metode total sampling sebanyak 43 orang. Data yang digunakan dalam penelitian ini adalah data primer yang diambil secara langsung dari responden menggunakan instrumen kuisioner EPDS dan lembar ceklist dukungan suami, serta data sekunder yang diperoleh dari data di Dinas Kesehatan Kabupaten Rejang Lebong dan Register Ibu Nifas di BPM dalam wilayah kerja Puskesmas perumnas kabupaten Rejang Lebong. Kuesioner terdiri dari 10 pertanyaan tentang perasaan responden dalam satu minggu terakhir.

Masing-masing pertanyaan Data dianalisis menggunakan analisis univariat dan bivariate. Untuk mengetahui hubungan antar variabel digunakan uji Chi-Square $\left(X^{2}\right)$, untuk mengetahui keeratan hubungan menggunakan uji statistik Contigency Coefficient.

\section{HASIL PENELITIAN}

\section{Karakteristik Responden}

Analisis ini di lakukan untuk mendapatkan gambaran tentang distribusi frekuensi masing-masing karakteristik responden dan kejadian postpartum blues

\section{Tabel 1. Distribusi Frekuensi Postpartum blues}

\begin{tabular}{|c|c|c|c|}
\hline Variabel & kategori & frekuensi & $\%$ \\
\hline Postpartum & & 11 & 25.6 \\
\hline \multirow[t]{3}{*}{ blues } & Berat & & \\
\hline & ringan & 18 & 41.9 \\
\hline & normal & 14 & 32.6 \\
\hline \multirow{3}{*}{$\begin{array}{c}\text { Dukungan } \\
\text { suami }\end{array}$} & & 20 & 46.5 \\
\hline & Mendukung & & \\
\hline & $\begin{array}{c}\text { Tidak } \\
\text { mendukung }\end{array}$ & 23 & 53.5 \\
\hline \multirow[t]{2}{*}{ paritas } & Multipara & 21 & 48.8 \\
\hline & Primipara & 22 & 51.2 \\
\hline \multirow[t]{3}{*}{ umur } & $<20$ tahhun & 30.2 & 13 \\
\hline & 20-35 tahun & 62.8 & 27 \\
\hline & 3 & 7.0 & 3 \\
\hline \multirow{3}{*}{$\begin{array}{c}\text { Tingkat } \\
\text { pendidikan }\end{array}$} & Dasar & 19 & 44.2 \\
\hline & Menengah & 16 & 37.2 \\
\hline & Tinggi & 8 & 18.6 \\
\hline
\end{tabular}

Berdasarkan tabel 1 dapat dilihat bahwa dari 43 orang ibu postpartum, $11(25,6 \%) \mathrm{ibu}$ mengalami gejala postpartum berat, 18 $(41,9 \%)$ ibu mengalami gejala postaptum ringan dan $14 \quad(32,6 \%)$ ibu menjalani postpartum dengan normal. Kelompok usia terbanyak berada pada rentang 20-35 tahun. Sekitar separuh ibu adalah primipara. Hampir setengah $19(44,2 \%)$ ibu berada pada tingkat pendidikan dasr. Lebih dari setengah 20 $(53,5 \%)$ ibu postpartum tidak memperoleh dukungan suami.

\section{Analisis Bivariat}

Untuk menguji hipotesa yang telah ditetapkan yaitu mempelajari hubungan antara variabel dengan menggunakan uji chisquare, untuk keperluan analisa dan uji 
statistik dilakukan pengabungan kategori dari variabel independen dalam penelitian ini, terlihat dari tabel di bawah ini:

Tabel 2. Hubungan pendidikan dengan Postpartum Blues di Puskesmas perumnas kabupaten Rejang Lebong

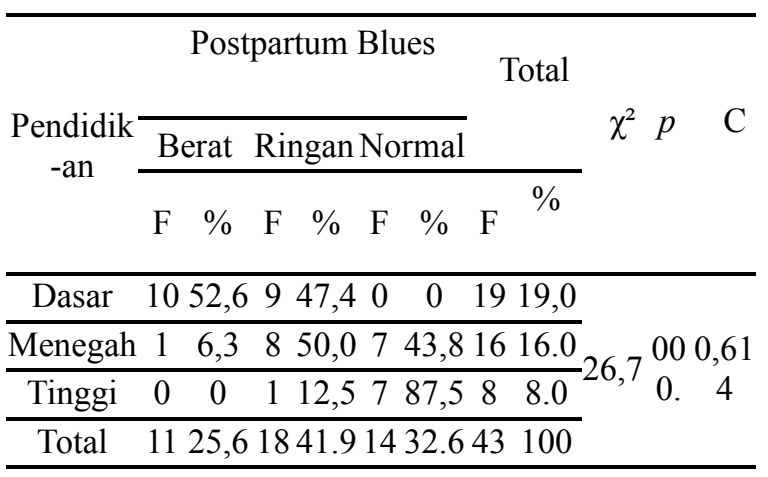

Berdasarkan tabel di atas dari 19 orang responden dengan pendidikan Dasar terdapat 10 orang postpartum blues berat dan 9 orang postpartum blues ringan, dari 16 orang responden yang berpendidikan menengah terdapat 1 orang postpartum blues berat 8 orang postpartum blues ringan dan 7 orang postpartum blues normal, dari 8 orang pendidikan tinggi terdapat 1 orang post partum blues ringan dan 7 orang post partum blues normal. maka digunakan uji statistik Pearson Chi-square $\left(\chi^{2}\right)$. Hasil uji Chi-square didapat nilai $\chi^{2}=26,076$ dengan nilai $\mathrm{p}=$ $0,000<0,05$ berarti signifikan maka Ho ditolak dan Ha diterima. Jadi Ada hubungan antara tingkat pendidikan dengan kejadian post partum blues. Hasil uji Contingency Coefficient didapat nilai $\mathrm{C}=0,614$ dengan niali $\mathrm{p}=0,000<0,05$ berarti signifikan.

Tabel 3. Hubungan usia dengan Postpartum Blues di Puskesmas Perumnas Kabupaten Rejang Lebong

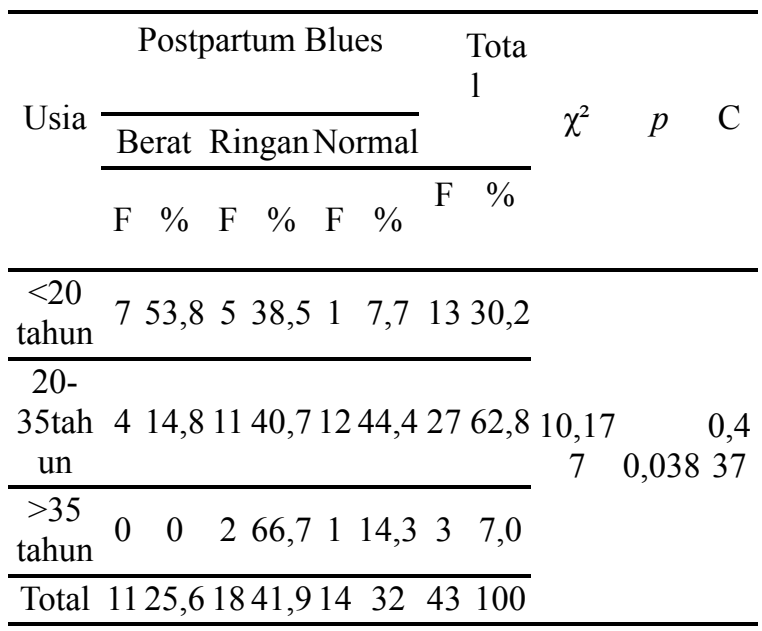

Berdasarkan tabulasi silang antara usia dan postpartum blues diatas dapat diketahui dari 13 orang usia $<20$ tahun terdapat 7 orang post partum blues berat 5 orang post partum blues ringan dan 1 orang post partumblues normal, dari 27 orang usia 20-35 tahun terdapat 4 orang post partum blues berat 11 orang post partum blues ringan dan 12 orang post partumblues normal, dari 3 orang usia $>35$ tahun terdapat 2 orang postpartum blues ringan dan 1 orang post partum blues normal. maka digunakan uji statistik Pearson Chisquare $\left(\chi^{2}\right)$ didapat nilai $\chi^{2}=10,177$ dengan nilai $\mathrm{p}=0,038<0,05$ berarti signifikan maka Ho ditolak dan Ha diterima.

Tabel 4. Hubungan paritas dengan Post partum Blues di Puskesmas Perumnas Kabupaten Rejang Lebong

\begin{tabular}{|c|c|c|c|c|}
\hline \multirow{3}{*}{ Paritas } & Postpartum Blues & \multirow{3}{*}{$\chi^{2}$} & \multirow{3}{*}{$P$} & \multirow{3}{*}{$\mathrm{C}$} \\
\hline & Berat Ringan Normal & & & \\
\hline & $\begin{array}{llllllll}\mathrm{F} & \% & \mathrm{~F} & \% & \mathrm{~F} & \% & \mathrm{~F} & \%\end{array}$ & & & \\
\hline Primipara & $\begin{array}{llllll}8 & 36,411 & 50 & 3 & 13,622 & 51,2 \\
\end{array}$ & & & \\
\hline Multipara & $3 \quad 14,3733,31152,42148,8$ & $\begin{array}{r}7,7 \\
4\end{array}$ & 0,02 & $\begin{array}{c}0,3 \\
90\end{array}$ \\
\hline Total & $1125,61841,914 \quad 32 \quad 43100$ & & & \\
\hline
\end{tabular}

Berdasarkan analisis antara paritas dan postpartum blues diatas dapat diketahui dari 22 orang paritas primipara terdapat 8 orang post partum blues berat 11 orang post partum blues ringan dan 3 orang postpartum blues normal, dari 21 orang paritas multipara terdapat 3 orang post partum blues berat 7 orang post partum blues ringan dan 11 orang 
normal. Karena syarat uji terpenuhi maka digunakan uji statistik post partum blues Pearson Chi-square $\left(\chi^{2}\right)$ didapat nilai $\chi^{2}$ $=7,714$ dengan nilai $p=0,021<0,05$ berarti signifikan maka Ho ditolak dan Ha diterima.

Tabel 5. Hubungan Dukungan Suami dengan Postpartum Blues di Puskesmas Perumnas Kabupaten Rejang Lebong

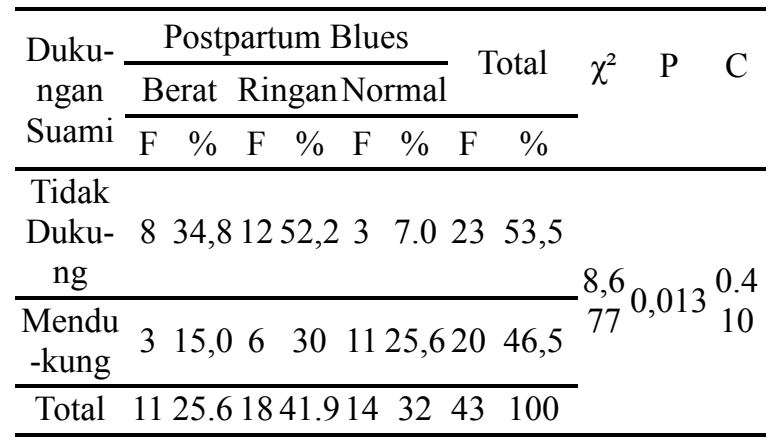

Hasil tabulasi silang dukungan suami dengan post partum blues di atas menunjukkan dari 23 orang suami tidak mendukung terdapat 8 orang post partum blues berat 12 orang post partum blues ringan dan 3 orang post partumblues normal, dari 20 orang suami mendukung terdapat 3 orang post partum blues berat 6 orang post partum blues ringan dan 11 orang post partumblues normal. Karena syarat uji terpenuhi maka digunakan uji statistik Pearson Chi-square $\left(\chi^{2}\right)$. Hasil uji Pearson Chi-square didapat nilai $\chi^{2}=8,677$ dengan nilai $\mathrm{p}=0,013<0,05$ berarti signifikan maka Ho ditolak dan $\mathrm{Ha}$ diterima. Jadi Ada hubungan antara dukungan suami dengan kejadian post partum blues Puskesmas Perumnas Kabupaten Rejang Lebong. Hasil uji Contingency Coefficient didapat nilai $\mathrm{C}=0,410$ dengan nilai $\mathrm{p}=0,013<0,05$ berarti signifikan.

\section{PEMBAHASAN}

Hasil penelitian ini diperoleh dari 43 responden berpendidikan Dasar sebanyak 19 orang dan sebagian besar mengalami postpartum blues berat yaitu 10 orang dan 9 orang postpartum blues ringan dan tidak ada yang normal hal ini dipengaruhi oleh
Pendidikan seseorang yang sangat berpengaruh terhadap pengetahuan dan kesiapan seorang ibu dalam menjalani kehamilan dan persalinan serta kesiapan seseorang merawat bayinya.

Responden yang tingkat pendidikan menengah SMA, MAN, yaitu 16 orang responden, yang mengalami postpartum berat 1 orang pada ibu primipara yang kurang mendapat dukungan suami, 43,8\% ibu yang berpendidikan menengah tidak mengalami postpartum blues hal ini karna pendidikan seseorang yang mempengaruhi cara berpikir dan cara pandang terhadap diri dan lingkungannya karena itu akan berbeda sikap responden yang mempunyai tingkat pendidikan tinggi dibandingkan yang berpendidikan rendah dalam menyikapi proses selama persalinan dan selama nifas berlangsung. responden dengan pendidikan yang rendah memiliki peluang besar untuk mengalami kejadian post partum blues bila tidak mendapatkan pantauan yang tepat dari keluarga dan tenaga kesehatan.

Hasil penelitian ini antara usia dengan postpartum blues diatas dapat diketahui dari 13 orang usia $<20$ tahun terdapat 7 orang post partum blues berat hal ini di sebabkan oleh faktor usia yang belum siap menerima peran baru dalam merawat bayi dan masa nifas yang berlangsung, terdapat 5 orang post partum blues ringan dan hanya 1 orang yang tidak mengalami postpartum blues pada ibu usia $<20$. dari 27 orang usia $20-35$ tahun terdapat 4 orang post partum blues berat karena kurangnya dukungan suami pada saat menjalani masa nifas, 11 orang post partum blues ringan dan 12 orang normal, dari 3 orang usia $>35$ tahun terdapat 2 orang postpartum blues ringan hal ini di alami responden dengan usia ibu diatas 37 tahun dan 38 tahun ibu mulai merasa kelelahan dalam proses persalinan.

Penelitian ini dilakukan pada fase taking hold (3-10 hari postpartum), ibu baru belum memperoleh cukup infomrasi dan pengalaman. Sehingga diketahui ada hubungan antara usia dan paritas dengan kejadian postpartum blues. Sejalan dengan 
penelitian yang dilakukan Irawati (2014) didapatkan bahwa umur yang mengalami postpartum blues adalah usia $<20$ tahun dan $>35$ tahun, usia tersebut merupakan usia berisiko bagi perempuan untuk melahirkan seorang bayi. Sebuah penelitian di Portugal juga menunjukkan hal serupa dimana kehamilan remaja berisiko tiga kali lipat mengalamni kecemasan dibandingkan dengan ibu yang hamil pada usia dewasa. Faktor terbesar yang berhubungan dengan hal ini adalah tingginya tuntutan peran dan pasangan yang kurang mendukung (Figueiredo, B, et al, 2007). Hal ini sesuai dengan data BKKBN (2012) yang menyatakan bahwa usia ideal wanita untuk hamil dan melahirkan adalah pada rentang usia 20-35 tahun sehingga dalam proses kehamilan lebih siap dan lebih matang.

Hasil penelitian ini antara paritas dan postpartum blues dapat diketahui dari 22 orang paritas primipara terdapat 8 orang post partum blues berat hal ini karna pada ibu paritas primipara merasa cemas dan merasa pengalamn baru dalam merawat bayidan mendapat peran baru yang rumit, 11 orang post partum blues ringan dan 3 orang postpartum blues normal di sebabkan pendidikan ibu usia ibu dan dukungan suami selama hamil dan nifas, dari 21 orang paritas multipara terdapat 3 orang post partum blues berat yang terjadi pada ibu yang tidak mendapat dukungan suami 7 orang post partum blues ringan dan 11 orang normal.

Penelitian ini 22 responden dengan Paritas primipara dengan postpartum blues berat lebih besar daripada responden dengan paritas multipara ini artinya ibu primipara mengalami dua kali lipat lebih besar mengalami postpartum blues, juga berperan terhadap terjadinya depresi. Ibu yang melahirkan anak pertama lebih berisiko mengalami depresi. Hal ini dikarenakan faktor ibu paritas primipara yang belum berpengalaman, juga peran sebagai seorang ibu dan segala yang berkaitan dengan peran baru dalam merawat bayinya merupakan.

Ibu primipara juga memiliki risiko postpartum blues sebagai dampak dari kecemasan mereka tentang perubahan bentuk tubuh dan dukungan sekitar. Walaupun multipara juga memungkinkan mengalami kecemasan pada kondisi kurangnya dukungan sosial dari orang terdekat (CH, Hung, 2007).

Responden yang post partum blues diketahui dari 23 orang suami tidak mendukung terdapat 8 orang post partum blues berat 12 orang post partum blues ringan dan 3 orang postpartum tidak mengalami postpartum blues,dalam penelitian ini bentuk dukungan yang diberikan suami adalah memberikan dukungan untuk memeriksakan kesehatan nya selama kehamilan dan persalinan serta mengantar ibu untuk memeriksakan kehamilannya, sedangkan dari 20 orang suami mendukung terdapat 3 orang post partum blues berat, 6 orang post partum blues ringan dan 11 orang tidak mengalami Postpartum blues.

Penelitian ini terdapat 3 orang responden yang mengalami postpartum blues berat meskipun mendapat dukungan suami hal ini disebabkan adanya faktor lain yang mempengaruhi ibu antara lain faktor ekonomi, riwayat kehamilan dan persalinan yang kurang baik, kematian orang tua disaat responden hamil sehingga merasa sering menangis karna masih teringat kematian ibunya dan responden sering berandai andai ibunya masih ada tentu segala sesuatu akan mudah di kerjakan dalam merawat bayinya kecemasan dan khawatir tidak mampu merawat bayinya dan lebih sering menyalahkan dirinya,dan pada faktor ekonomi yang kurang menyebabkan suami meskipun mendukung namun masih mempengaruhi pikiran ibu dalam perawatan bayinya yang berhubungan dengan kesehatan psikologi ibu.

Menurut peneliti, dukungan sosial yang merupakan respon ataupun sikap yang ditunjukkan oleh lingkungan sekitar ibu post partum terhadap ibu post partum tersebut. Dengan adanya dukungan sosial dari orangorang terdekat akan sangat membantu ibu post partum dalam menghadapi dan melewati hari-hari pertama pasca persalinan sehingga dapat mencegah terjadinya syndrome baby 
blues karena tidak adanya perhatian dan tempat berbagi untuk melewati hariharipertama pasca persalinan. kurangnya dukungan sosial dari suami dan keluarga merupakan penyebab terjadinya masalah emosional pada periode postpartum. Untuk itu pada ibu post partum perlu diberikan dukungan baik secara psikologis, material maupun instrumental agar mampu melalui masa post partum dengan baik. Hal itu bisa dilakukan dengan cara membantu ibu baru menyesuaikan diri secara positif dan sehat untuk peran baru mereka, tanggung jawab, dan identitas sebagai ibu. Memberikan waktu istirahat yang cukup, memenuhi kebutuhannya dan melibatkan keluarga, atau suami dalam merawat bayi akan mengurangi masalah emosianal ibu yang bisa menyebabkan post partum blues. Bagi tenaga kesehatan pentingnya memberikan informasi tentang tanda dan karakteristik postpartum blues, memberikan health education tentang perawatan ibu setelah melahirkan dan cara merawat bayi bisa mengurangi kecemasan ibu yang bisa menyebabkan terjadinya postpartum blues.

\section{KESIMPULAN}

Penelitian ini menunjukkan adanya hubungan yang signifikan antara pendidikan, usia, paritas, dan dukungan suami dengan kejadian postpartum blues di wilayah kerja Puskesmas Curup.

\section{SARAN}

Mengenali faktor risiko diharapkan dapat digunakan sebagai bahan pertimbangkan dalam upaya mencegah masalah ini. Studi yang lebih lanjut dengan jumlah sampel yang lebih besar masih perlu dilakukan.

\section{DAFTAR PUSTAKA}

BKKBN. 2018. Survei Demografi dan Kesehatan Indonesia 2017: Kesehatan Reproduksi Remaja. Jakarta: BKKBN

$\mathrm{CH}$, Hung. 2007. The psychosocial for primiparas and multiparas. NCBI.Kaoshiung J Med Sci. 23 (7) 352360

Dira, I and Wahyuni, A. (2016). Prevalensi dan Faktor -Faktor Risiko post partum Blues di kota denpasar menggunakan edinburgh postnatal depresion scala.Denpasar Tahun 2015 E-Jurnal Medika. 5 (7), 1-5

Fairus, M and Widianti, S. (2014). Hubungan dukungan suami dengan kejadian depresi postpartum pada ibu nifas. Jurnal Kesehatan Metro Sai Wawai. 8 (1), 11-18

Fuguiredo, B, et al (2007) Teenage pregnanacy, attachment style and adult pregnanatwomen in a Portuguese series. Attachment \& Human Develupoment.Taylor \& Francis Group. 8(2). 123-138

Irawati, D and Yuliani, F. (2014). Pengaruh Faktor Psikososial Terhadap Terjadinya Postpar-tum Blues pada Ibu Nifas (Studi di Ruang Nifas RSUD R.A Basoeni Mojokerto ). Hos-pital Majapahit. 6(1), 1-14

K. L. Wisner, B. L. Parry, C. M. Piontek. 2002, Postpartum Depression N Engl J Med. 347(3). 194-199

Kurniasari, D and Astuti, YA. 2015. Hubungan antara Karakteristik ibu, kondisi bayi da dukungan sosial suami dengan postpartum blues pada ibu dengan persalinan sc di Rumah Sakit Umum Ahmad Yani Metro Tahun 2014. Jurnal Kesehatan Holistik. 9 (3). 115-125

Maryunani, A (2010) Asuhan Kegawatdaruratan Maternal \& Neonatal. Jakarta. Trans Info Media

Muraca, G and Joseph K (2014). The association between maternal age and Depression. Women's Health. J Obstet Gynaecol Can. 36(9). 803-810

Nugroho, T. (2014) Buku Ajar Asuhan Kebidanan Nifas. Jakarta. Salemba Medika.

Setyowati, YD, Krisnatuti, D, Hastuti D. 2017. Pengaruh kesiapan menjadi orang tua dan pola asuh psikososial terhadap perkembanagn sosial anak. Jurnal Ilmu 
Keluarga \& Konseling. 1 (2). 95-106

Wahyuni, S, Murwati, and Supiati. (2014)

Faktor internal dan eksternal yang mempengaruhi depresi postpartum.

Jurnal Terpadu Ilmu Kesehatan. 3(2).

106-214 